\title{
PEMANFAATAN SOFTWARE GEOGEBRA DALAM PEMBELAJARAN MATEMATIKA
}

\author{
Putri Fitriasari \\ Universitas PGRI Palembang \\ Email : putrifitriasari20@gmail.com
}

\begin{abstract}
The use of computer applications in teaching and learning mathematics are coming to the fore these days. One of the applications is Geogebra. This dynamic software provides features that can be effectively integrated into learning mathematics. Because, GeoGebra provides demonstrations and visualizations for many mathematical concepts. Also, it encourages students to construct such concepts. Therefore, Geogebra is very useful to help students visualize and manipulate abstract mathematical objects easily.
\end{abstract}

Keywords : GeoGebra

\begin{abstract}
Abstrak
Pemanfaatan program komputer dalam pembelajaran matematika merupakan kebutuhan pada zaman sekarang ini. Banyak sekali program-program computer yang dapat digunakan dalam pembelajaran matematika antara lain adalah GeoGebra. GeoGebra adalah program dinamis yang beragam fasilitasnya dapat dimanfaatkan sebagai media pembelajaran matematika. Selain itu GeoGebra dapat digunakan untuk mendemonstrasikan atau memvisualisasikan konsep-konsep matematis serta alat bantu untuk mengkonstruksi konsep-konsep tersebut. Dengan program GeoGebra, objekobjek matematika yang bersifat abstrak dapat divisualisasi sekaligus dapat dimanipulasi secara cepat dan efisien.
\end{abstract}

Kata Kunci : GeoGebra

\section{PENDAHULUAN}

Perkembangan ilmu pengetahuan yang sangat pesat dan juga sejalan dengan berkembangnya teknologi yang semakin canggih sangat berpengaruh dan memberi manfaat dalam kehidupan kita. Perkembangan ilmu pengetahuan dan teknologi tersebut pada dasarnya akan bermanfaat untuk lebih mempermudah manusia dalam menjalankan segala aktivitas di berbagai bidang kehidupan. Salah satu contohnya pada bidang pendidikan termasuk pendidikan matematika.

Matematika sebagai salah satu bidang dalam pembelajaran di sekolah merupakan bidang yang mendapat perhatian dalam pengembangan pembelajarannya. Mata 
pelajaran matematika di SMP misalnya yang cenderung abstrak. Hal ini menyebabkan matematika merupakan salah satu mata pelajaran yang dianggap sulit bagi siswa. Salah satu bagian dari matematika yang bersifat abstrak adalah geometri. Menurut Aliviah (2012) selama ini pembelajaran geometri di kelas tersebut hanya diajarkan menggunakan media papan tulis dan belum memanfaatkan media pembelajaran seperti komputer. Penyampaian materi yang sering dilakukan guru adalah berupa pembelajaran konvensional seperti ceramah, sehingga ada siswa yang mengalami kesulitan untuk memahami materi yang disampaikan. Untuk itu dibutuhkan media lain yang dapat membantu pemahaman siswa mengenai geometri tersebut.

Menurut Kustandi (2011) dalam pendidikan, media difungsikan sebagai sarana untuk mencapai tujuan pembelajaran. Karena informasi yang terdapat dalam media harus dapat melibatkan siswa, baik dalam benak atau mental maupun dalam bentuk aktivitas yang nyata, sehingga pembelajaran dapat terjadi. Materi harus dirancang secara lebih sistematis dan psikologis, serta ditinjau dari segi prinsip- prinsip belajar agar dapat menyiapkan instruksi belajar yang efektif. Di samping menyenangkan, media pembelajaran harus dapat memberikan pengalaman dan memenuhi kebutuhan individu siswa, karena setiap siswa memiliki kemampuan yang berbeda.

Alternatif media pembelajaran yang sesuai dengan perkembangan zaman saat ini dan dapat membantu guru dalam hal penyampaian materi yang bersifat abstrak adalah media komputer. Salah satu program komputer (software) yang dapat dimanfaatkan dalam pembelajaran matematika khususnya geometri adalah GeoGebra. Program ini dapat dimanfaatkan untuk meningkatkan pemahaman siswa terhadap konsep yang telah dipelajari maupun sebagai sarana untuk mengenalkan atau mengkonstruksi konsep baru. Menurut Hohenwarter (2008), program GeoGebra sangat bermanfaat bagi guru maupun siswa. Tidak sebagaimana pada penggunaan program komersial yang biasanya hanya bisa dimanfaatkan di sekolah, Geogebra dapat diinstal pada komputer pribadi dan dimanfaatkan kapan dan di manapun oleh siswa.

Berdasarkan hal di atas maka penulis tertarik untuk menulis artikel dengan judul Pemanfaatan Software GeoGebra untuk Pembelajaran Matematika. Artikel ini menyajikan uraian mengenai program GeoGebra beserta contoh-contoh penggunaan GeoGebra sebagai media pembelajaran matematika. 


\section{PEMBAHASAN}

\section{Software GeoGebra}

Program komputer sangat ideal untuk dimanfaatkan dalam pembelajaran konsepkonsep matematika yang menuntut ketelitian tinggi. Misalnya penyelesaian grafik secara tepat, cepat, dan akurat (Kusumah, 2003). Lebih lanjut Kusumah juga mengemukakan bahwa inovasi pembelajaran dengan bantuan komputer sangat baik untuk diintegrasikan dalam pembelajaran konsep-konsep matematika, terutama yang menyangkut transformasi geometri, kalkulus, statistika, dan grafik fungsi.

Berbagai pemanfaatan komputer dalam pembelajaran matematika dimaksudkan untuk mendukung dan memfasilitasi siswa dalam memahami konsep-konsep matematika. Dengan demikian, pemahaman konsep siswa harus mendapatkan prioritas utama daripada hanya meningkatan kemampuan mekanistik siswa dalam memanfaatkan program komputer. Dalam hal ini bimbingan guru sangat diperlukan guna mengaitkan berbagai animasi atau aplikasi program komputer yang dihasilkan siswa dengan konsepkonsep yang relevan dan mendasarinya. Dalam banyak hal, pemahaman konsep haruslah mendahului berbagai pemanfaatan program komputer. Meskipun demikian, dalam batas-batas tertentu, program komputer dapat dimanfaatkan dalam proses pengkonstruksian konsep oleh siswa. Walaupun berdasarkan fungsinya, media pembelajaran komputer dapat diterapkan pada tahap penanaman konsep, pemahaman konsep, dan pembinaan keterampilan penguasaan konsep. Tahap pembelajaran pemahaman konsep menitikberatkan pada penguasaan dan perluasan wawasan siswa tentang konsep yang telah dipelajari pada tahap penanaman konsep. Sedangkan tahap pembelajaran pembinaan keterampilan penguasaan konsep menitikberatkan pada pembinaan keterampilan siswa menerapkan konsep yang telah dipelajari.

Salah satu program komputer (software) yang dapat digunakan sebagai media pembelajaran matematika adalah program GeoGebra. GeoGebra dikembangkan oleh Markus Hohenwarter pada tahun 2001. GeoGebra adalah program komputer (software) untuk membelajarkan matematika khsusunya geometri dan aljabar (Hohenwarter, 2008).

Menurut Hohenwarter (2008), program GeoGebra sangat bermanfaat bagi guru maupun siswa. Tidak sebagaimana pada penggunaan software komersial yang biasanya hanya bisa dimanfaatkan di sekolah, Geogebra dapat diinstal pada komputer pribadi dan dimanfaatkan kapan dan di manapun oleh siswa. Bagi guru, GeoGebra menawarkan 
kesempatan yang efektif untuk mengkreasi lingkungan belajar online interaktif yang memungkinkan siswa mengeksplorasi berbagai konsep-konsep matematika.

Menurut Mahmudi (2010) pemanfaatan program GeoGebra memberikan beberapa keuntungan, diantaranya adalah sebagai berikut:

1. Lukisan-lukisan geometri yang biasanya dihasilkan dengan dengan cepat dan teliti dibandingkan dengan menggunakan pensil, penggaris, atau jangka.

2. Adanya fasilitas animasi dan gerakan-gerakan manipulasi (dragging) pada program GeoGebra dapat memberikan pengalaman visual yang lebih jelas kepada siswa dalam memahami konsep geometri.

3. Dapat dimanfaatkan sebagai balikan/evaluasi untuk memastikan bahwa lukisan yang telah dibuat benar.

4. Mempermudah guru/siswa untuk menyelidiki atau menunjukkan sifat-sifat yang berlaku pada suatu objek geometri.

Menurut Hohenwarter \& Fuchs (2004), GeoGebra sangat bermanfaat sebagai media pembelajaran matematika dengan beragam aktivitas sebagai berikut:

1. Sebagai media demonstrasi dan visualisasi

Dalam hal ini, dalam pembelajaran yang bersifat tradisional, guru memanfaatkan GeoGebra untuk mendemonstrasikan dan memvisualisasikan konsep-konsep matematika tertentu.

2. Sebagai alat bantu konstruksi

Dalam hal ini GeoGebra digunakan untuk memvisualisasikan konstruksi konsep matematika tertentu, misalnya mengkonstruksi lingkaran dalam maupun lingkaran luar segitiga, atau garis singgung.

3. Sebagai alat bantu proses penemuan

Dalam hal ini GeoGebra digunakan sebagai alat bantu bagi siswa untuk menemukan suatu konsep matematis, misalnya tempat kedudukan titik-titik atau karakteristik grafik parabola.

Sebelum program GeoGebra dapat digunakan pada komputer Anda harus mengunduh aplikasi GeoGebra terlebih dahulu. Aplikasi GeoGebra tersedia di situs http://www.geogebra.org/. untuk megunduh file ini silahkan masuk ke situs tersebut kemudian pilih link Installer. Installer GeoGebra juga tersedia dalam beberapa platform berbeda. Pilih installer yang sesuai dengan sistem operasi yang anda gunakan. Setelah 
installer selesai didownload kemudian jalankan instalasi dan ikuti langkah instalasi sampai selesai.

Menu utama GeoGebra adalah: File, Edit, View, Option, Tools, Windows, dan Help untuk menggambar objek-objek geometri. Menu File digunakan untuk membuat, membuka, menyimpan, dan mengekspor file, serta keluar program. Menu Edit digunakan untuk mengedit lukisan. Menu View digunakan untuk mengatur tampilan. Menu Option untuk mengatur berbagai fitur tampilan, seperti pengaturan ukuran huruf, pengaturan jenis (style) objek-objek geometri, dan sebagainya. Sedangkan menu Help menyediakan petunjuk teknis penggunaan program GeoGebra. Berbagai menu selengkapnya disajikan pada gambar berikut ini.

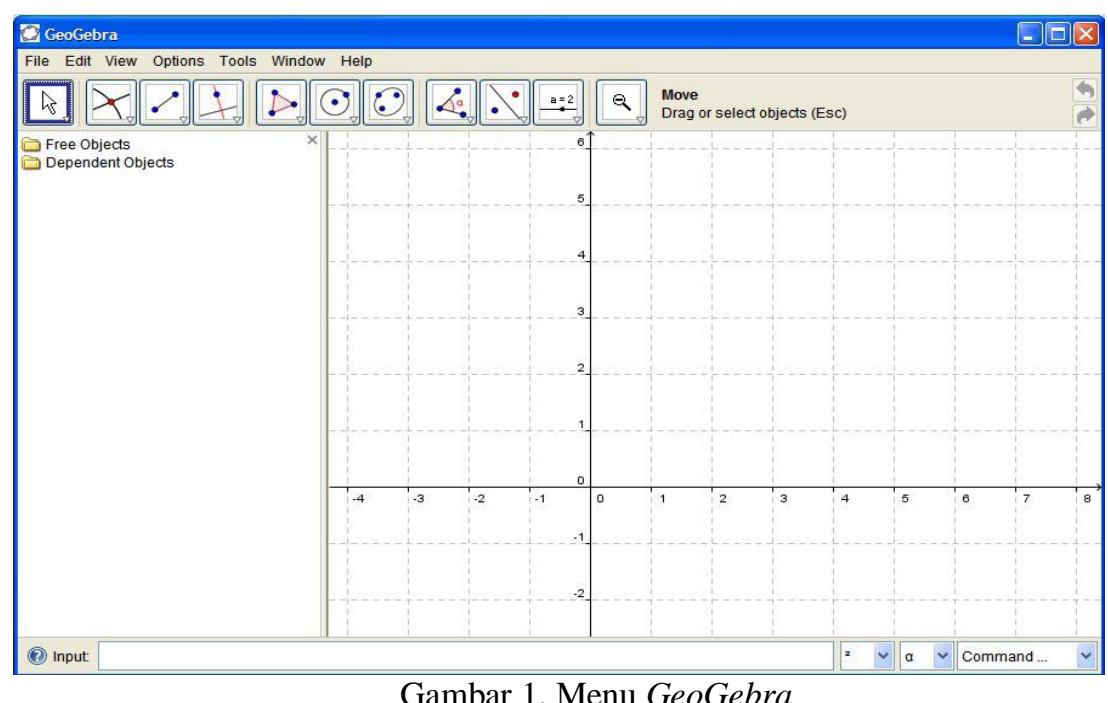

Kelebihan GeoGebra

1. Free software

2. Dapat digunakan pada berbagai sistem operasi (Windows, MacOS, Linux)

3. Didukung lebih dari 40 bahasa.

4. Support 3D

5. Publish Web. File .ggb pada GeoGebra dapat dipublish sebagai web. Ini memudahkan siswa untuk menggunakannya, karena cukup menggunakan browser (IE, Mozilla, Chrome, dll) untuk berinteraksi. Dengan kata lain, pada komputer siswa tidak harus terinstal GeoGebra. Namun tentu saja harus dipastikan sudah terinstal Java versi terbaru.

6. Easy to Use. Kemudahan di sini adalah setiap tombol dan syntax pada GeoGebra selalu disertai dengan instruksi dan bantuan penggunaan. 
Kelemahan GeoGebra adalah harus selalu mengupdate Java, kecuali menginstall versi offline.

\section{Contoh Aplikasi Program GeoGebra}

Pada bagian ini akan disajikan beberapa pemanfaatan program GeoGebra, yakni untuk menemukan bahwa dua sudut yang saling bertolak belakang besarnya selalu sama dan menyelesaikan persamaan linier dua variabel.

GeoGebra dapat digunakan untuk menemukan bahwa dua sudut yang saling bertolak belakang itu besarnya selalu sama. Langkah-langkah yang harus dilakukan adalah sebagai berikut.

- Membuat dua garis yang saling berpotongan dengan tool line through two points

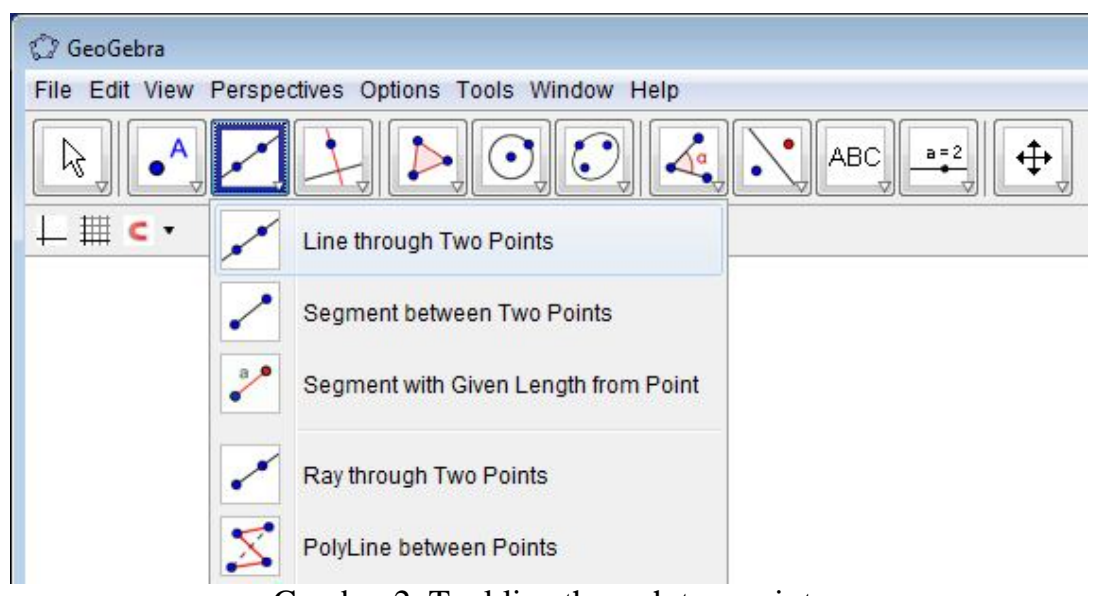

Gambar 2. Tool line through two points

- Menentukan titik potong kedua garis tersebut dengan tool intersection two objects



Gambar 3. Tool intersection two objects

- Kemudian tool angle untuk menentukan besar semua sudut yang ada 


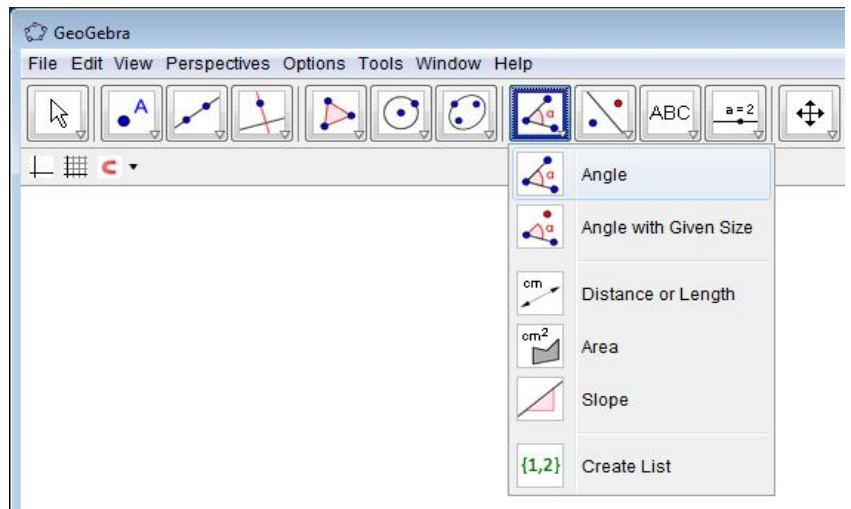

Gambar 4. Tool angle

Setelah langkah-langkah di atas dilaksanakan, maka gambar yang dihasilkan adalah sebagai berikut:

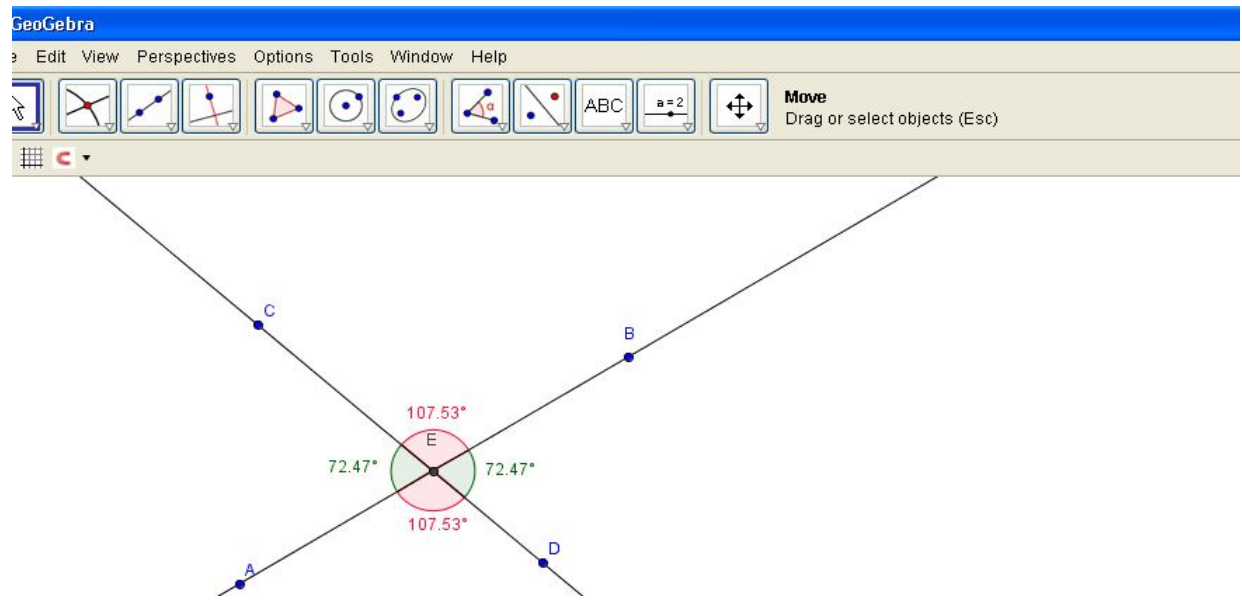

Gambar 5. Sudut bertolak Belakang

Dengan cara menggeser/menggerakkan titik A kesembarang arah, siswa diminta mengukur sudut yang terbentuk. Hal ini dilakukan lagi kemudian siswa diminta mengukur lagi. Dengan cara ini maka siswa dapat menemukan bahwa sudut yang bertolak belakang besarnya selalu sama.

Selain itu, dengan kemampuan untuk menggambar grafik suatu persamaan, GeoGebra dapat dimanfaatkan untuk mencari penyelesaian sistem persamaan linier. Sebagai contoh kita dapat mencari penyelesaian suatu sistem persamaan linier. Seperti kita ketahui bahwa penyelesaian untuk sistem persamaan linier dua variabel dapat dilakukan dengan beberapa cara, salah satunya dengan metode grafik. Dengan GeoGebra, penyelesaian metode grafik dapat dilakukan secara mudah. Sebagai contoh kita menyelesaikan sistem persamaan linier dua variabel berikut dengan GeoGebra. Langkah-langkahnya adalah sebagai berikut. 
1. Ketikkan pada menu input bar persamaan $2 x+y=15$. Ini berguna untuk menggambar grafik suatu persamaan.

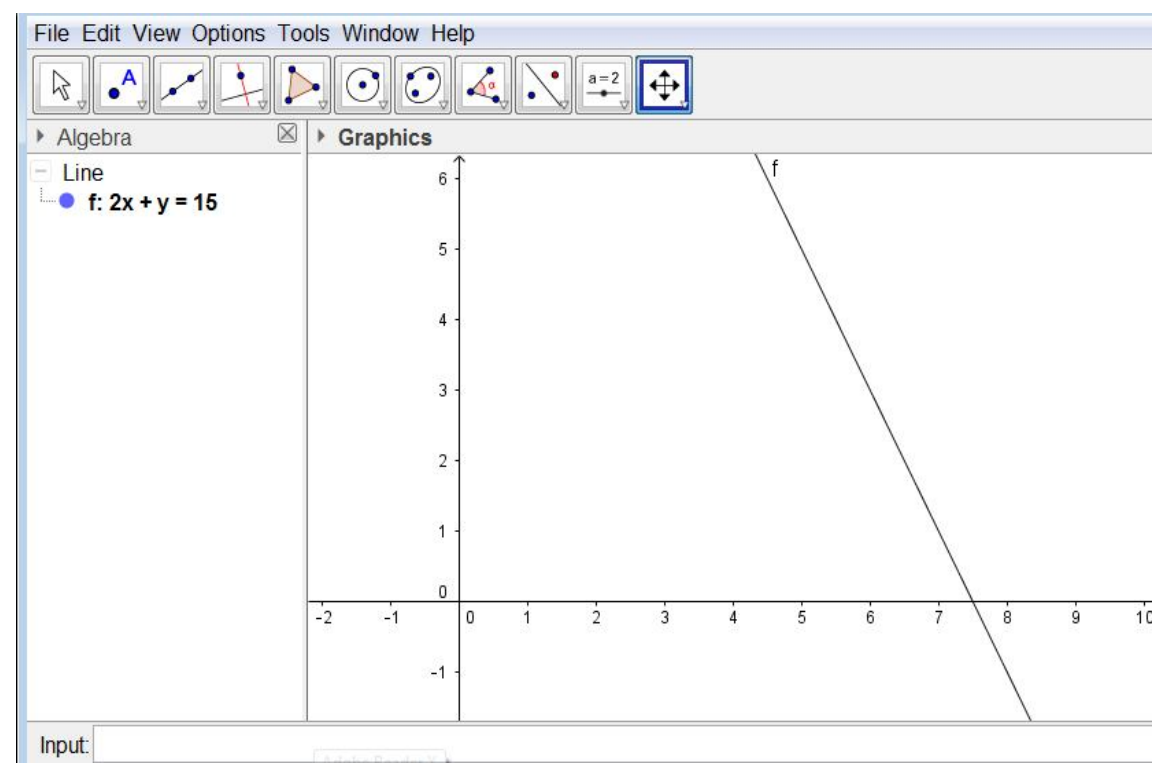

2. Pada menu input bar masukkan lagi persamaan $x+2 y=18$

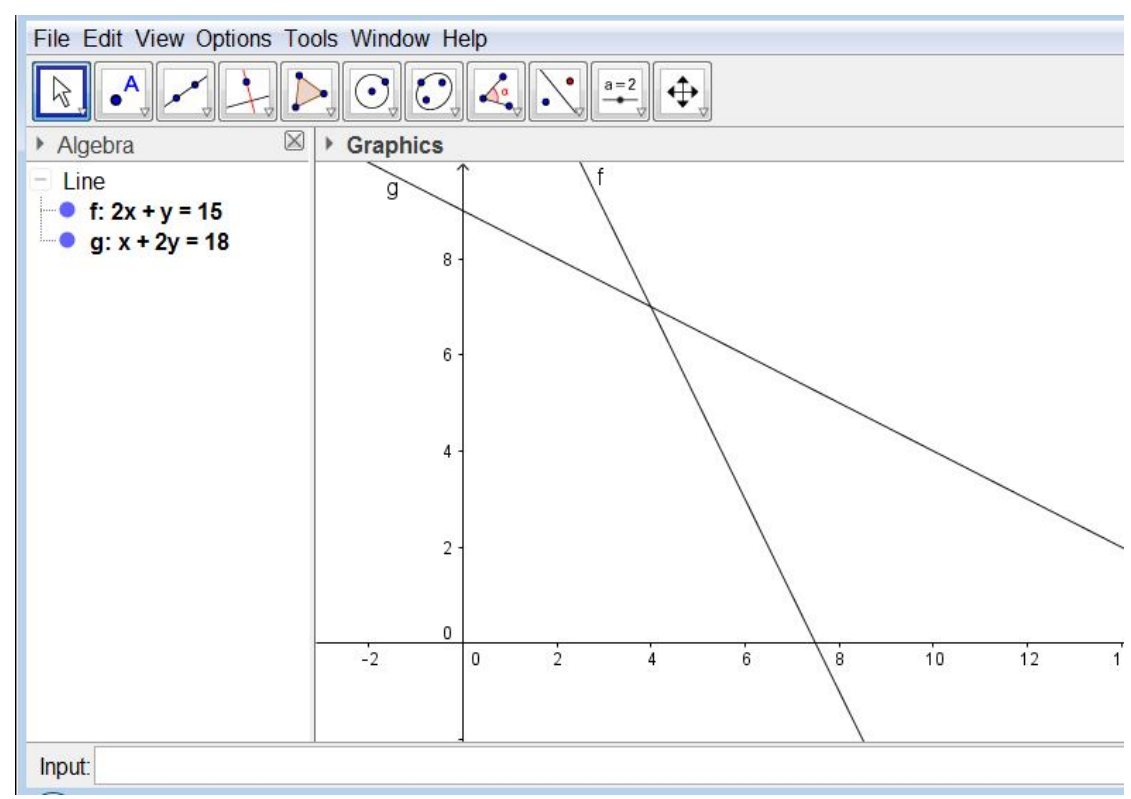

3. Pilih tool intersect (perpotongan garis) Intersect kemudian klik kedua garis tersebut secara begantian.

4. Perhatikan tampilan algebra (aljabar) pada kolom sebelah kiri, titik potong (titik A) antara kedua garis tersebut adalah penyelesaiannya. 


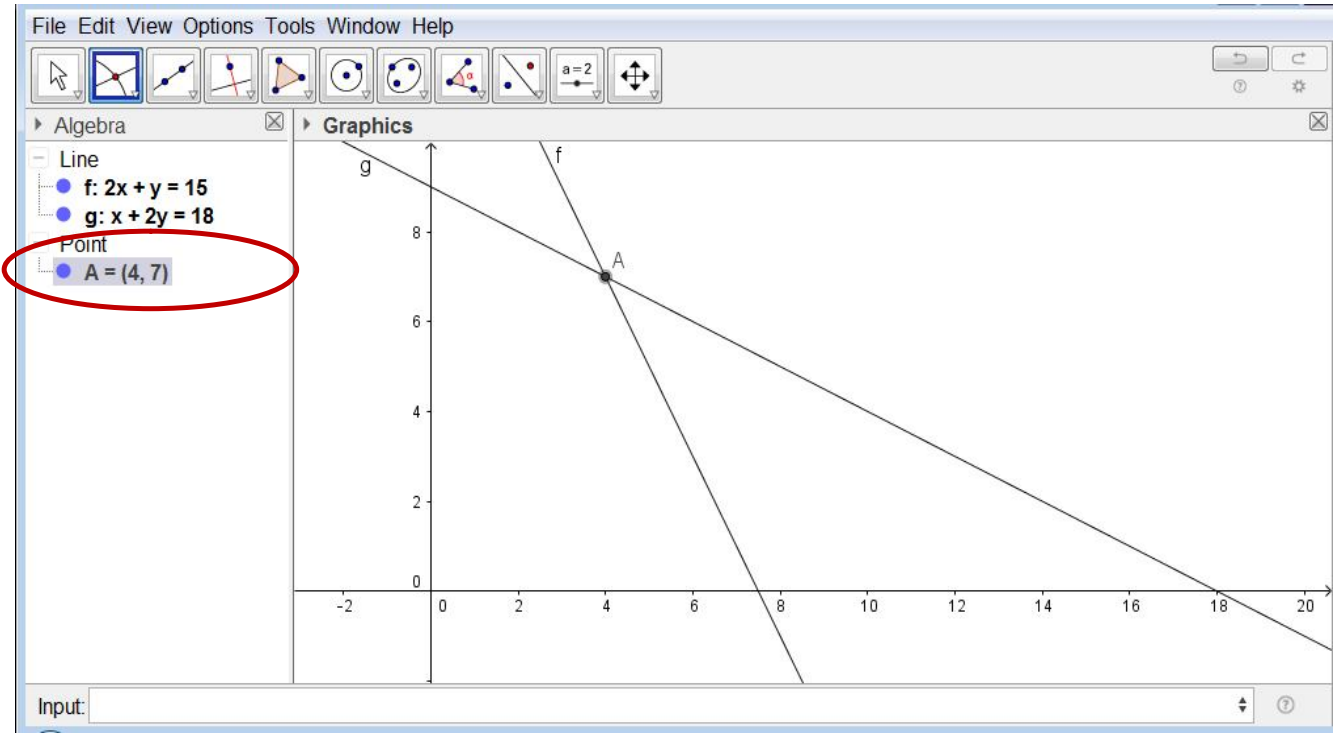

5. Penyelesaikan sistem persamaan linier dua variabel.

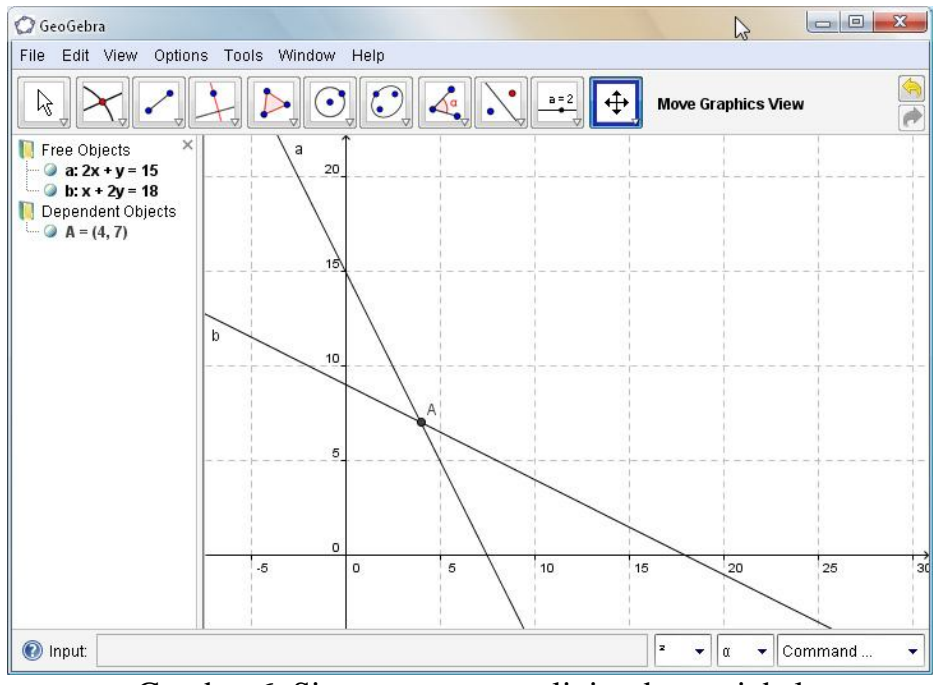

Gambar 6. Sistem persamaan linier dua variabel

Contoh Soal

Maksimumkan $\mathrm{F}(\mathrm{x}, \mathrm{y})=450 \mathrm{x}+320 \mathrm{y}$.

Dengan syarat $\left\{\begin{array}{l}121 \mathrm{x}+235 \mathrm{y} \leq 625 \\ 425 \mathrm{x}+123 \mathrm{y} \leq 872 \\ \mathrm{x} \geq 0 \\ \mathrm{y} \geq 0 \\ \mathrm{x}, \mathrm{y} \text { anggota } \mathrm{R}\end{array}\right.$

Langkah-langkah yang digunakan sebagai berikut:

1. Buka program geogebra 
2. Pada menu masukkan (input) masukkan ketikkan persamaan $121 \mathrm{x}+235 \mathrm{y}=625$, dan $425 x+123 y=872 ;$ maka akan tampil seperti gambar berikut

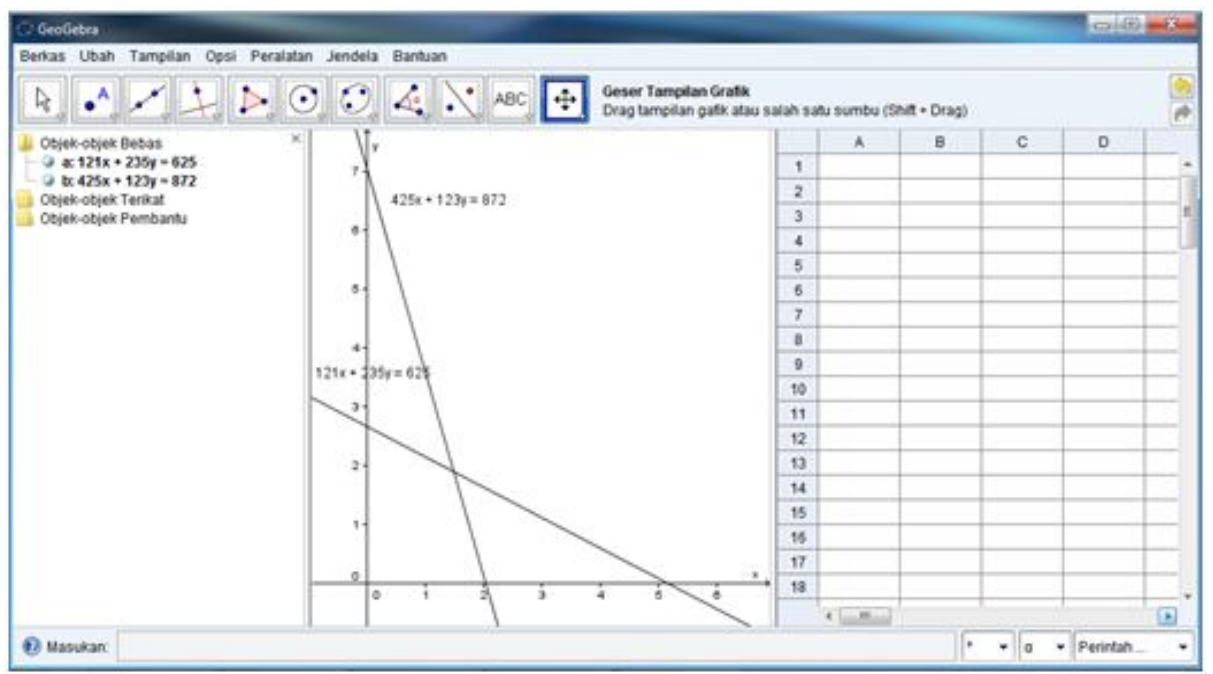

3. Kemudian tentukan titik potong masing-masing garis dengan terlebih dahulu menseleksi tool perpotongan dua objek

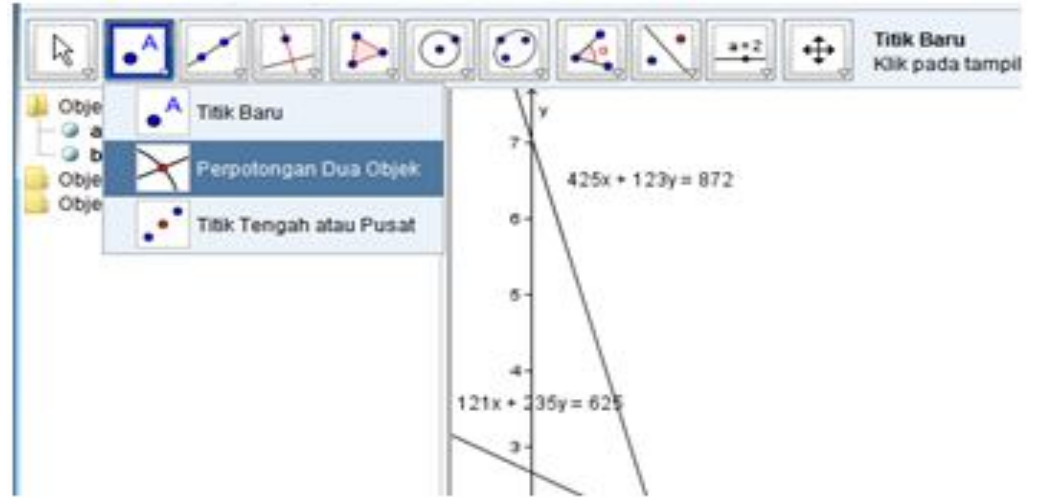

Sehingga diperoleh titik potong masing-masing garis dengan hanya cukup klik pada masing-masing garis yang akan dicari titik potongnya, sehingga diperoleh 4 titik seperti gambar berikut:




5. Kemudian klik tool poligon seperti gambar:

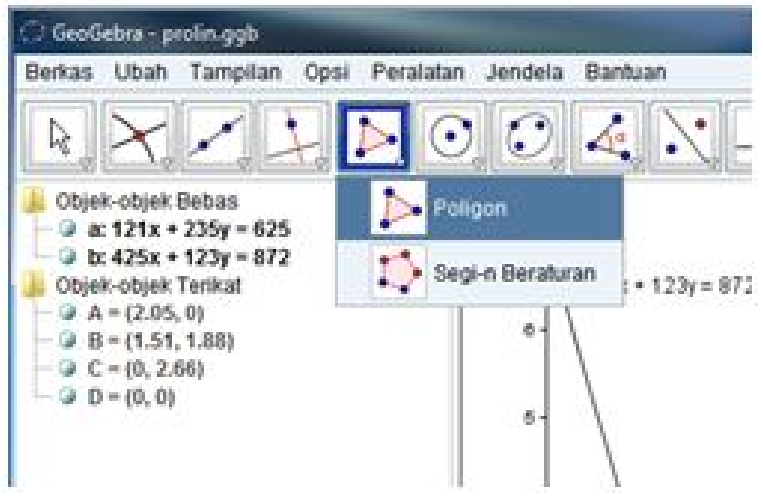

Hubungkan keempat titik tersebut sehingga diperoleh daerah penyelesaiannya seperti berikut:

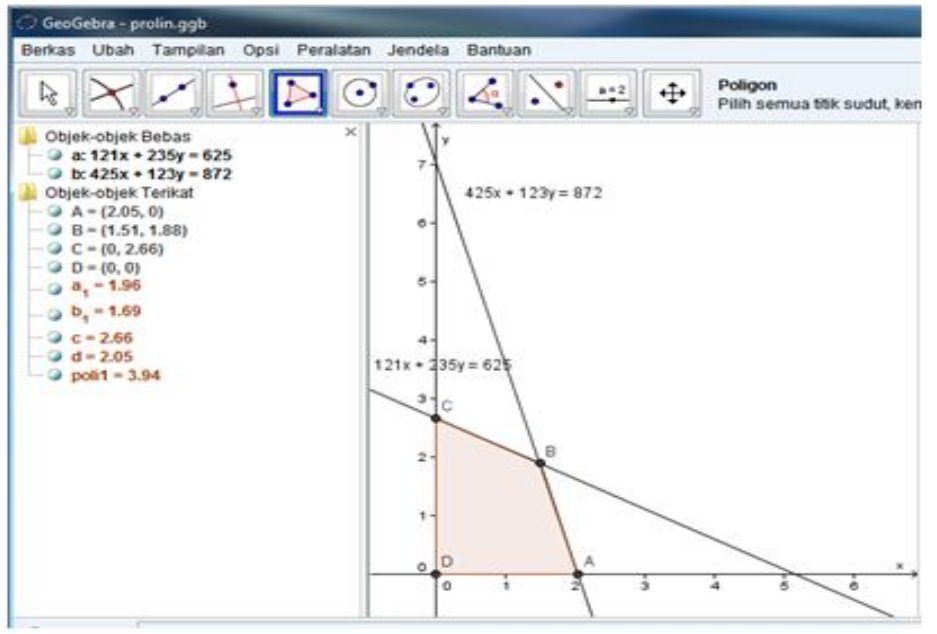

6. Kemudian, titik-titik potong tersebut kita masukkan ke bilah spreedshet dengan cara mengetikkan titik potong tersebut pada spreadsheat misalnya A, B, C, seperti gambar:




7. Selanjutnya pada kolom nilai ketikkan penyelesaiannya sebagai berikut: $(450 * 2.05)+(320 * 0)$ untuk titik $A$, dan seterusnya untuk masing-masing titik, maka sudah dapat disimpulkan nilai maksimumnya. Sehingga diperoleh nilai seperti gambar:

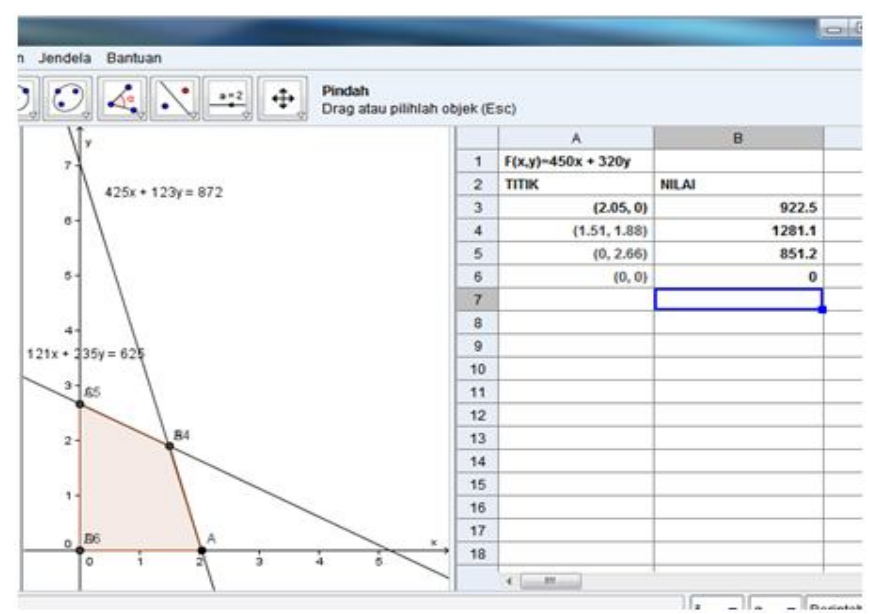

\section{SIMPULAN}

Program GeoGebra dapat dimanfaatkan sebagai media pembelajaran matematika dengan beragam fasilitasnya. GeoGebra adalah software matematika dinamis yang menggabungkan geometri, aljabar, dan kalkulus. Selain itu GeoGebra adalah sistem geometri dinamik, kita dapat melakukan konstruksi dengan titik, vektor, ruas garis, garis, irisan kerucut, begitu juga dengan fungsi, dan mengubah hasil konstruksi selanjutnya. Persamaan dan koordinat dapat dimasukan secara langsung. Jadi, GeoGebra memiliki kemampuan menangani varabel-peubah untuk angka, vektor, titik, menemukan turunan dan integral dari suatu fungsi, dan menawarkan perintah-perintah seperti akar atau nilai ekstrim.

\section{DAFTAR PUSTAKA}

Alviah, E.E., \& Rudhito, M. A. 2012. Efektifitas pembelajaran dengan program geogebra disbanding pembelajaran konvensional pada topic grafik fungsi kuadrat $\begin{array}{llll}\text { kelas } & X & \text { SMA pangudi luhur Yogyakarta. (online), }\end{array}$ (http://eprints.uny.ac.id/7562/1/P\%20-\%2030.pdf), diakses 11 Mei 2017.

Hohenwarter, M. 2008. Teaching and Learning Calculus with Free Dynamic Matgematics Software GeoGebra. (online), (http://www.publications.uni.lu/record/2718/files/ICME11-TSG16.pdf), diakses 15 Mei 2017.

Hohenwarter, M. \& Fuchs, K. 2004. Combination of Dynamic Geometry, Algebra, and Calculus in the Software System Geogebra. (online), (www.geogebra.org/publications/pecs_2004.pdf), diakses 8 Mei 2017. 
Kustandi, C., \& Bambang S. 2011. Media Pembelajaran; Manual dan Digital. Bogor: Penerbit Ghalia Indonesia.

Kusumah, Y. S. 2003. Desain dan Pengembangan Bahan Ajar Matematika Interaktif Berbasiskan Teknologi Komputer. Makalah disajikan dalam Seminar Proceeding National Seminar on Science and Math Education, FMIPA UPI Bandung bekerja sama dengan JICA.

Mahmudi, A. 2010. Membelajarkan Geometri dengan Program geogebra. (online), http://eprints.uny.ac.id/10483/1/P6-Ali\%20M.pdf, diakses 8 Mei 2017. 